\title{
A Source for the Interpretation of Murillo's Parable of the Prodigal Son: The Golden Age Stage
}

\author{
Mindy Nancarrow Taggard
}

Volume 14, numéro 1-2, 1987

URI : https://id.erudit.org/iderudit/1073454ar

DOI : https://doi.org/10.7202/1073454ar

Aller au sommaire du numéro

Éditeur(s)

UAAC-AAUC (University Art Association of Canada | Association d'art des universités du Canada)

ISSN

0315-9906 (imprimé)

1918-4778 (numérique)

Découvrir la revue

Citer cet article

Taggard, M. N. (1987). A Source for the Interpretation of Murillo's Parable of the Prodigal Son: The Golden Age Stage. RACAR : Revue d'art canadienne / Canadian Art Review, 14(1-2), 90-95. https://doi.org/10.7202/1073454ar

\section{Résumé de l'article}

La série de six tableaux de Bartolomé Esteban Murillo intitulée La parabole de l'enfant prodigue (Collection Beit, Irlande) et réalisée à Séville entre 1660 et 1670, semble être la seule oeuvre picturale espagnole du dix-septième siècle qui porte sur ce thème biblique. Les estampes du graveur français de la même période, Jacques Callot, semblent avoir inspiré cette série unique, bien que la source d'inspiration des nombreuses adaptations apportées par Murillo, notamment au niveau des costumes, des personnages et des décors, n’ait pas encore été déterminée.

Cet article compare l'interprétation de Murillo de cette parabole à celle des dramaturges espagnols du Siècle d'or. Contrairement aux arts plastiques, la parabole a été un thème dramatique populaire qui a été repris tant dans le théâtre religieux que séculier par des dramaturges importants du dix-septième siècle comme Lope de Vega, Tirso de Molina et J. de Valdivielso. Les détails relatifs aux costumes dans El hijo pródigo de Lope semblent supposer que, dans la série de Murillo, le fait que l'enfant prodigue soit vêtu de vert à son départ symbolise sa naïveté, alors que le dialogue dans la comédie de Tirso suggère que la couleur rouge de sa cape reflète son humeur, soit son irresponsabilité et son étourderie. Cette comédie explique également le rôle important que joue le frère aîné : introduit dans le premier tableau comme l'image inverse de l'enfant prodigue, il offre à l'observateur un contre-exemple positif en regard des excès honteux de son jeune frère. Par ailleurs, le dialogue dans El hijo pródigo de Lope présente la vieille dans le tableau de Murillo de l'enfant prodigue chassé comme un personnage-clé au niveau de la représentation symbolique de son " desengaño ", soit son éveil à la vanité des plaisirs éphémères de la vie. Plus importante encore est l'interprétation offerte dans le scénario de Lope du tableau de l'enfant prodigue festoyant : en effet, il définit la courtisane comme l'incarnation des plaisirs de la chair, le vin une potion pour oublier et le péché de l'enfant prodigue sa perte de contrôle sur les cinq sens qui lui viennent de Dieu. L'étroite similarité entre la composition de Murillo et la scène de Lope laisse croire que le peintre, dans ce cas, s'est inspiré de l'oeuvre El hijo pródigo. La popularité du scénario, publié d'abord en 1604 et réimprimé à six autres reprises avant 1618, permet de conclure que Murillo avait pû facilement y avoir accès. Étant donné la censure artistique sévère qui existait alors en Espagne, la nature de la scène, qui représente l'indulgence des sens, explique que le peintre ait choisi une source espagnole plutôt qu'étrangère.
Tous droits réservés (C) UAAC-AAUC (University Art Association of Canada | Association d'art des universités du Canada), 1987
Ce document est protégé par la loi sur le droit d'auteur. L’utilisation des services d'Érudit (y compris la reproduction) est assujettie à sa politique d'utilisation que vous pouvez consulter en ligne.

https://apropos.erudit.org/fr/usagers/politique-dutilisation/ 


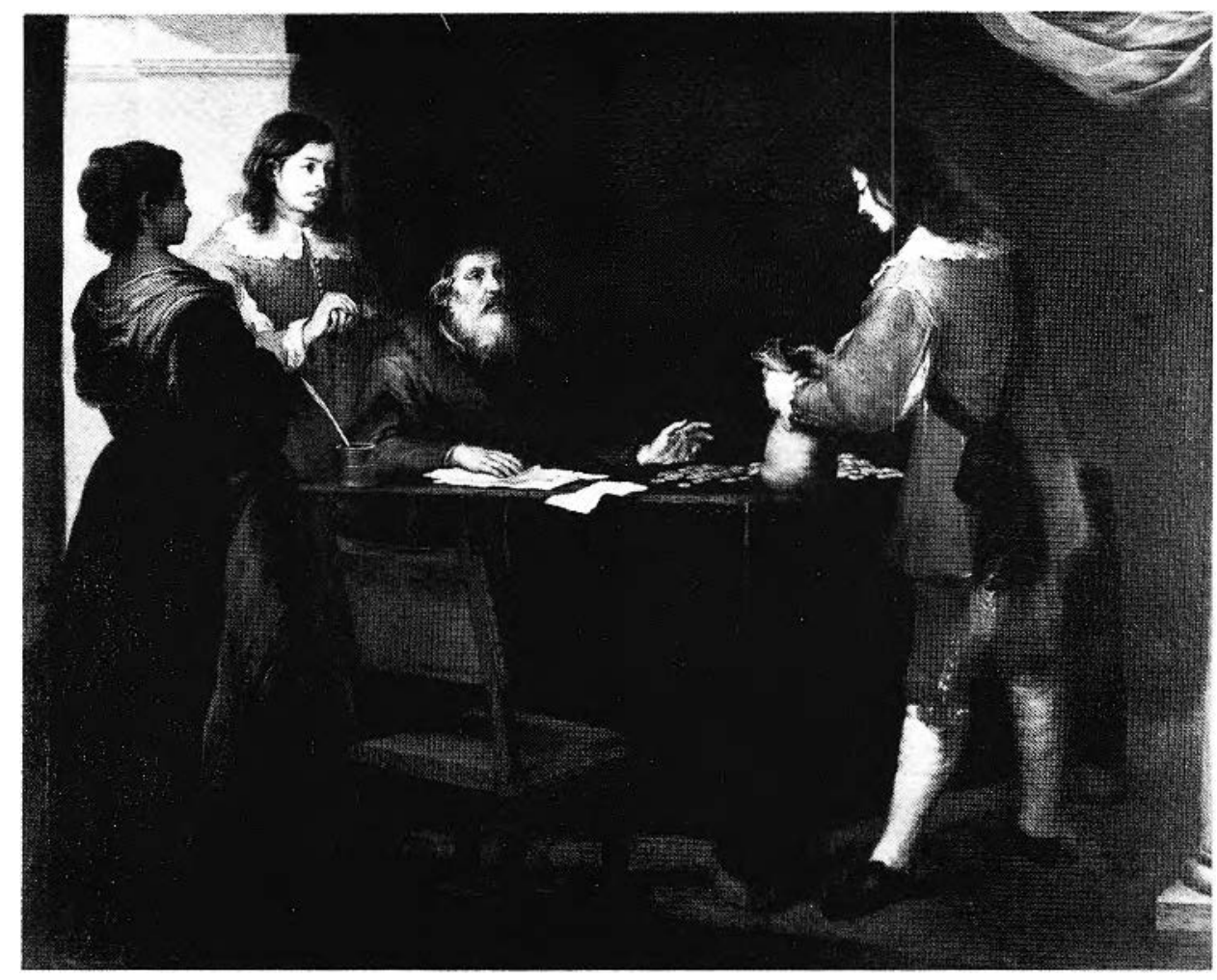

Figure 67. B. F.. Murillo, The Prodigal Son Receives his P'ortion $(104 \times 143 \mathrm{~cm}$.), ca. 1660-70. Blessington, Beit Foundation (Photo: Beit Foundation).

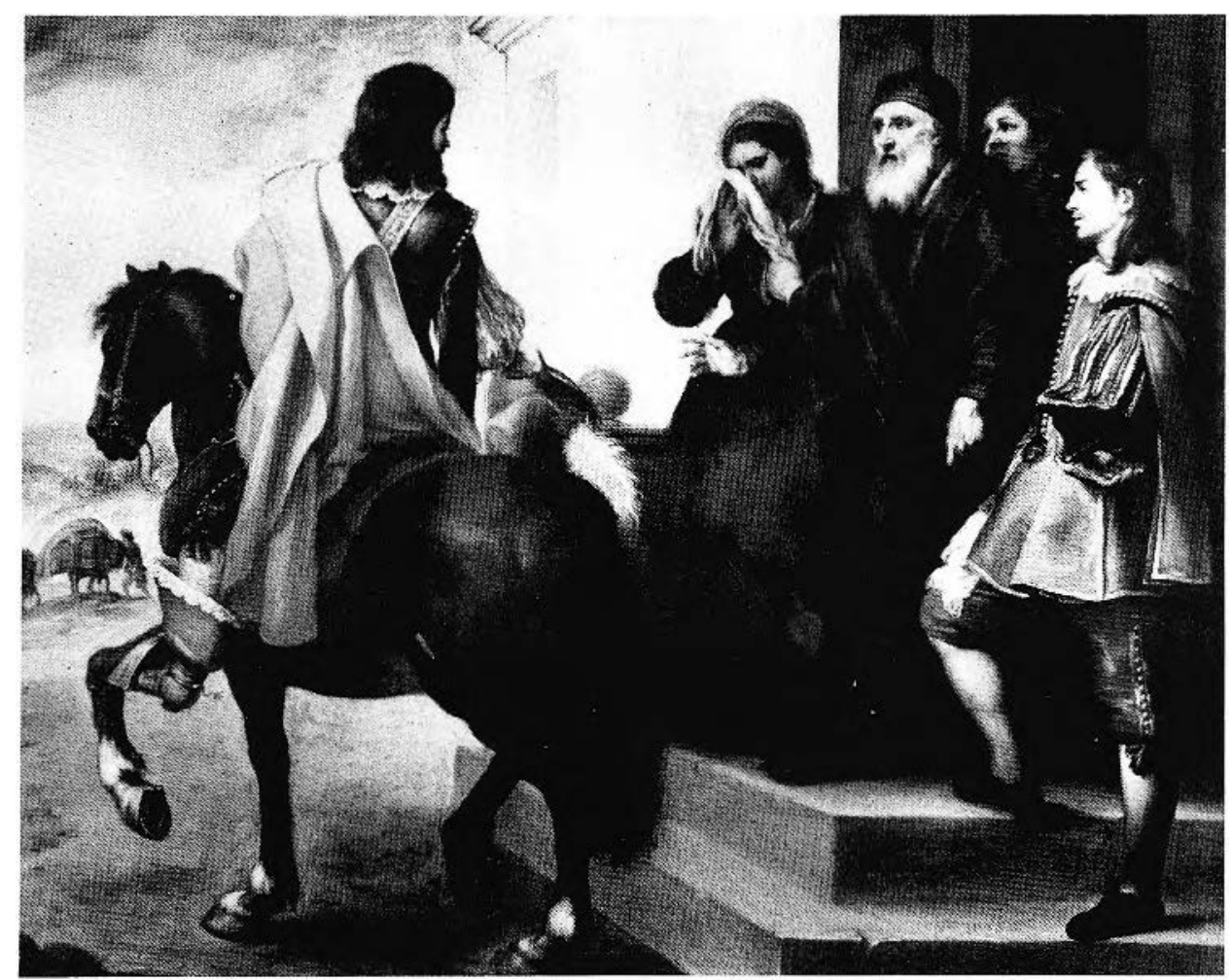

Figure 68. B. F. Murillo, The Departure of the Prodigal Son $(105 \times 135 \mathrm{~cm}$.), ca. 1660-70. Blessington, Beit Foundation (Photo: Beit Foundation). 


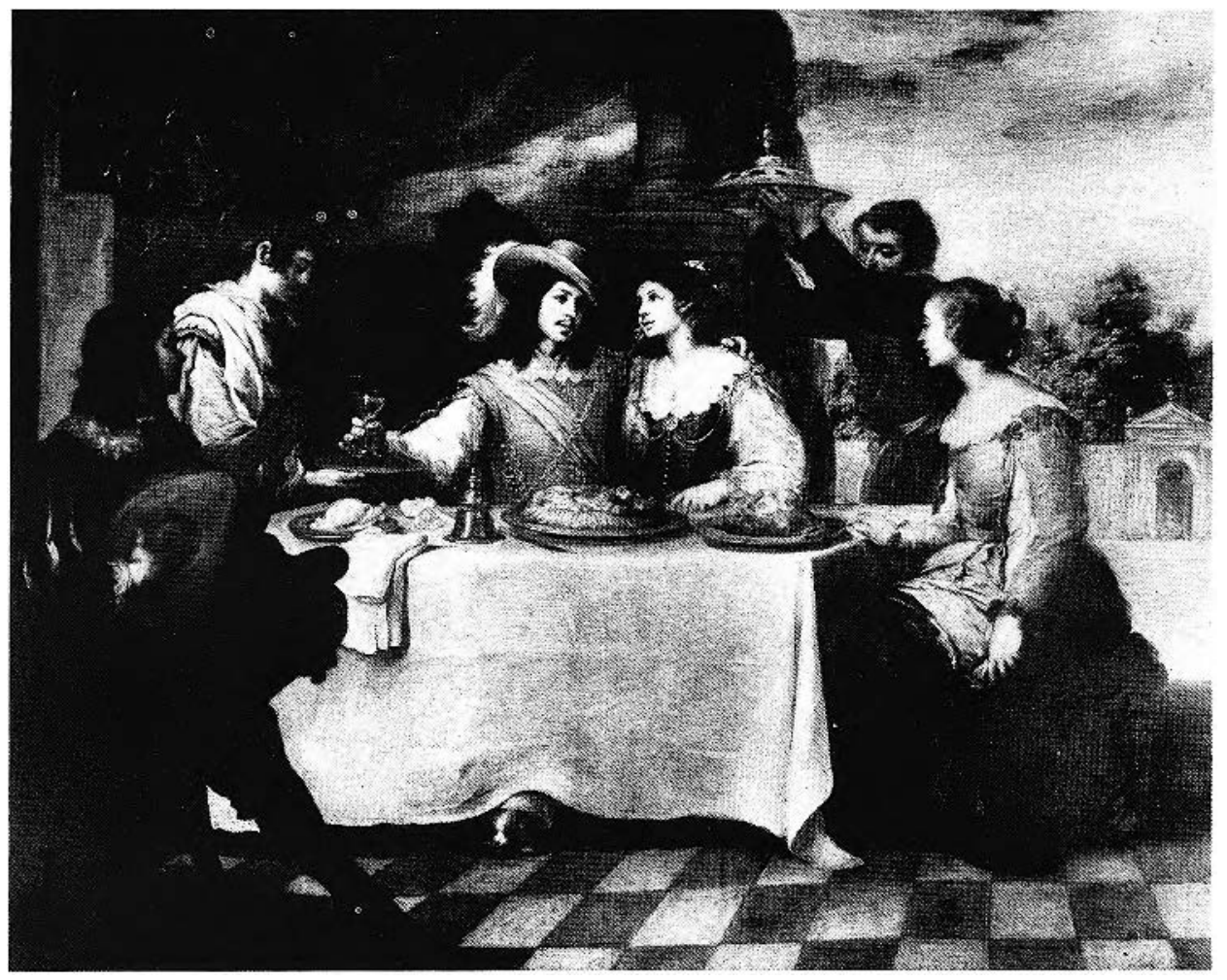

Figlre. 69. B. E. Murillo, The Prodigal Son Feasting $(105 \times 135 \mathrm{~cm}$.$) , ca. 1660-70. Bles-$ sington, Bcit Foundation (Photo: Beit Foundation).

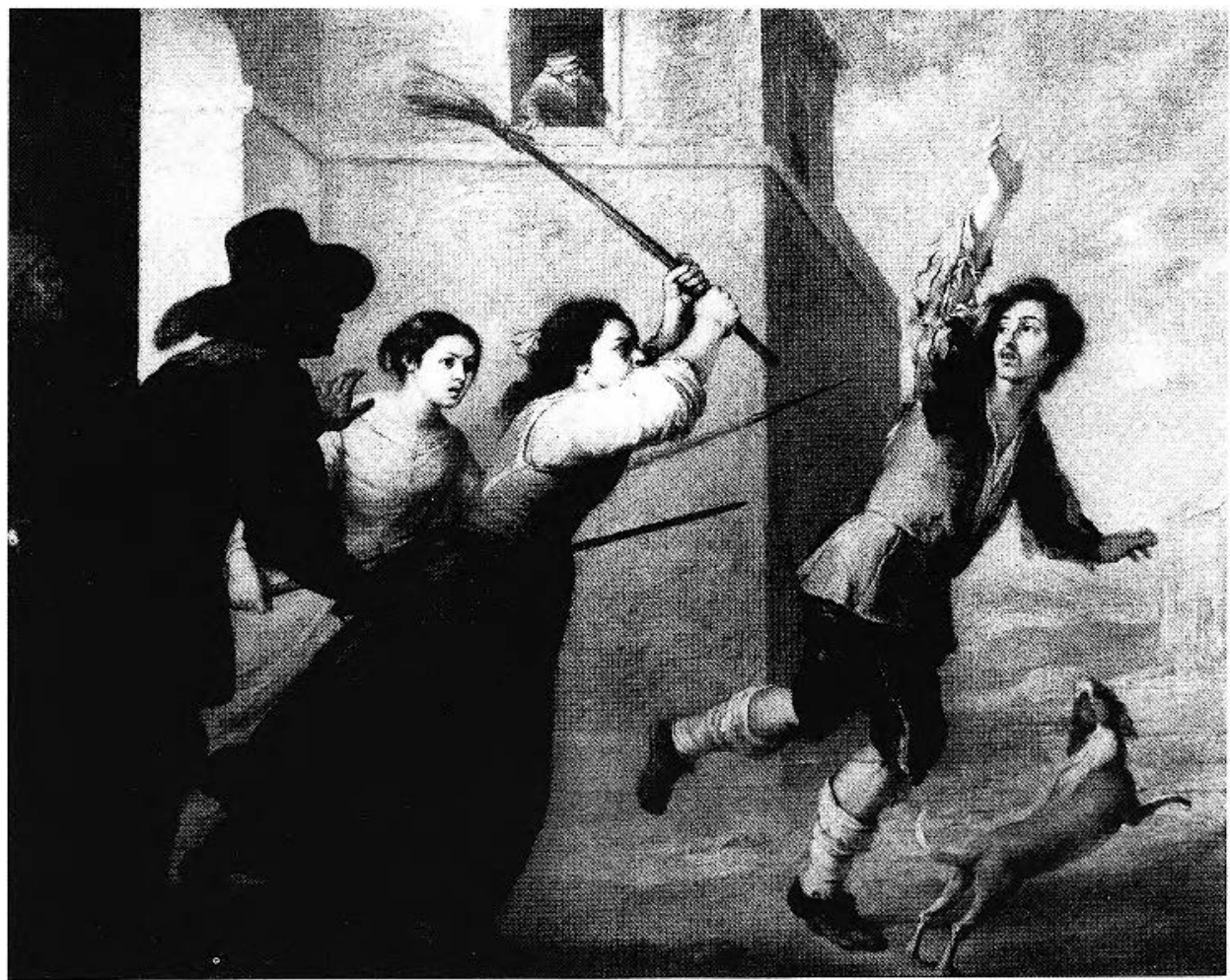

Figcre 70. B. E. Murillo, The Prodigal Son Thrown Out $(105 \times 135 \mathrm{~cm}$.), ca. 1660-70. Blessington, Beit Foundation (Photo: Beit Foundation). 


\title{
A Source for the Interpretation of Murillo's Parable of the Prodigal Son: The Golden Age Stage
}

\author{
MINDY NANCARROW TAGGARD \\ Oklahoma State University, Stillwater
}

\section{RÉSUMÉ}

La série de six tableaux de Bartolomé Esteban Murillo intitulée La parabole de l'enfant prodigue (Collection Beit, Irlande) et réalisée à Séville entre 1660 et 1670 , semble être la seulc oeuvre picturale espagnole du dix-septième siècle qui porte sur ce thème biblique. Lcs estampes du graveur français de la même période, Jacques Callot, semblent avoir inspiré cette séric unique, bien que la source d'inspiration des nombreuses adaptations apportées par Murillo, notamment au niveau des costumes, des personnages et des décors, n’ait pas encore été déterminéc.

Cet articlc compare l'interprétation de Murillo de cette parabole à celle des dramaturges espagnols du Siècle d'or. Contrairement aux arts plastiques, la parabole a été un thème dramatique populaire qui a été repris tant dans le théâtre religieux que séculier par des dramaturges importants du dix-septième siècle comme Lope de Vega, Tirso de Molina et J. de Valdivielso.

Les détails relatifs au x costumes clans El hijo pródigo de Lope semblent supposer que, dans la série de Murillo, le fait que l'cnfant prodigue soit vêtu de vert à son départ symbolise sa naïveté, alors que le dialogue dans la comédie de Tirso suggère que la coulcur rouge de sa cape reflète son humeur, soit son irresponsabilité et son étourderie. Cette comédie explique également le rôle important que joue le frère aîné : introduit dans le premier tableau comme l'image inverse de l'enfant prodigue, il offre à l'observateur un contre-exemple positif en regard des excès honteux de son jeune frère. Par ailleurs, le dialogue dans El hijo pródigo de Lope présente la vieille dans le tableau de Murillo de l'enfant prodigue chassé comme un personnage-clé au niveau de la représentation symbolique de son "desengaño ", soit son éveil à la vanité des plaisirs éphémères de la vie. Plus importante encore est l'interprétation offerte dans le scénario de Lope du tableau de l'enfant prodigue festoyant : en effet, il définit la courtisane comme l'incarnation des plaisirs de la chair, le vin une potion pour oublier et le péché de l'enfant prodigue sa perte de contrôle sur les cinq sens qui lui viennent de Dieu. L'étroite similarité entrc la composition de Murillo et la scène de Lope laisse croire que le peintre, dans ce cas, s'est inspiré de l'oeuvre El hijo pródigo. La popularité du scénario, publié d'abord en 1604 et réimprimć à six autres reprises avant 1618, permet de conclure que Murillo avait pû facilement y avoir accès. Etant clonné la censure artistique sévèrc qui existait alors en Fispagne, la nature de la scène, qui rcprésente l'indulgence des sens, explique que le peintre ait choisi une source espagnole plutôt qu'étrangèrc.
Bernard Dorival's article of $1951^{1}$ proved that Bartolomé Esteban Murillo’s (1617-1682) narrative of six canvases, The Parable of the Prodigal Son (Figs. 67-72; Bcit Collection, Blessington, Ireland), is based on a set of ten very small etchings produced in 1635 by the French printmaker Jacques Callot. ${ }^{2}$

1 Bernard Dorival, "Callot, modèle de Murillo," La Revue des Arts, 11 (1951), 94-101

2 The prints are catalogued and illustrated in Jules Lieure's Jacques Callot (New York: Collectors liditions, 1969), II, cat. nos. 1405-14. Spain's finest seventeenth-century painters
Painted in Seville ca. 1660-70, ${ }^{3}$ Murillo's series shows the strongest borrowings in its fourth and

frequently turned to northern European prints for compositional suggestions. See Martín S. Soria's fundamental article, "Some Flemish Sources of Baroque Painting in Spain," The Art Bulletin, xxx (1948), 249-59.

3 Scholars have dated the series anywhere from 1660 to 1680. Most recently, Diego Angulo Iñiguez, Murillo. Su vida, su arte, su obra (Madrid: Espasa-Calpe, S.A., 1981), II, 25, while not excluding the possibility that the canvases might correspond to a series of six paintings commissioned of Murillo about 1670, has proposed a date just prior to 1660 . 
fifth scenes. The Prodigal Son Thrown Out (Fig. 70), for example, repeats not only the figures of the angry courtesans (Fig. 74) but also the gesture of the Prodigal, his wildly waving arms, and even the sinall dog leaping at his feet.

Of course, Spain's finest late Baroque painter did not merely copy the prints of Callot. His alterations include ones of character, costume, and sctting. Most significantly, he reduced the Frenchman's large cast and focused on the psychology of the characters; he provided new costumes; and for most scenes he altered the settings. Dorival accounted for these and other changes by citing the fact that Murillo was Spanish rather than French and worked in a different period and medium from Callot. Convincing as these answers are, they fall short in an important way: they explain neither why the painter made the particular changes that he did nor what meaning (if any) he intended to introduce through these alterations.

For example, although it is not surprising that Murillo's Prodigal wears seventeenth-century Spanish rather than French clothes, why are his costumes coloured as they are? (Or again, although it is not remarkable that Murillo, painting in a classicizing, late-Baroque style, introduces fewer characters into the narrative than Callot, who worked in a courtly, mannerist tradition, why did he include the Prodigal's brother (Figs. 67-68) and an aged crone (Fig. 70), two figures notably absent from the Frenchman's series?

lo comprehend the painter's motives and grasp the subtler meanings of his compositions, I propose to explore a resource rarely utilized by historians of Spanish art: the scripts written for the Golden Age stage. ${ }^{4}$ For the purposes of this study, they are particularly rich sources, for during the sixteenth century and the first quarter of the seventeenth century the parable was dramatized at least six times. ${ }^{5}$

4 The Golden Age of Spanish draina is usually considered to range from 1500 to 1681, or from the appearance of Fernando de Rojas's Ciomedia de Calisto y Melibea to the death of the Madrid playwright Pedro Calderón de la Barca. Iwo other seventeenth-century Spanish paintings that have been related to the stage are Diego Velázquez's Surrender of Breda and Juan Bautista Maino's Recapture of Bahia (both Madrid, Prado). Carl Justi (Velázquez and his Times [London, H. Grevel, 1889], 359, linked the former to Calderon de la Barca's El sitio de Bredá, while Pedro Beroqui ("Adiciones y correciones al catálogo del museo del Prado," Boletin de la Sociedad Castellana de Excursiones, vi [1913-14], 539-45) connected the latter $(0)$ Lope de Vega's El Brasil restituido. For a full discussion, see Jonathan Brown and J. H. Elliott, $A$ Palace for a King (New Haven and London: Yale University Press, 1980), 178-92.

5 Perhaps seven. $\Lambda$ anonymous manuscript play preserved in Madrid's Biblioteca Nacional (Ms. 14893), "El hijo pródigo: de tres ingenios," also appears to be seventeenthcentury. Because it is undocumented and sometimes
First, the parable was loosely adapted as a comedy ${ }^{6}$ by Luis de Miranda, a sixteenth-century poet from Plasencia (Comedia del hijo pródigo, Seville, 1554). It was given a similar treatment by Félix Lope de Vega Carpio (1562-1635), Spain's most famous and prolific playwright, whose La prueba de los amigos, completed in 1604, awaited the nineteenth century for publication. ${ }^{7}$ The story was also dramatized by 'Tirso de Molina (pseudonym of the Mercedarian monk and playwright (rabriel Téllez, 1571-1648), whose Tanto es lo de más como lo de menos, written about 1620 and published in Seville in 1627, synthesizcs the parable of the Prodigal Son with the parable of the Rich Man and Poor Lazarus. ${ }^{8}$ Penned for the religious stage, in turn, is the anonymous mid-sixteenth-century Aucto del hijo pródigo, ${ }^{9}$ as well as Lope de Vega's one-act morality play El hijo pródigo, published in 1604, and the Toledan cleric José de Valdivielso's (ca. 1560-1638) auto sacramental (religious play coordinated with the feast of Corpus Christi) El hijo pródigo, which was largely based on the script written by his close friend Lope and published in Toledo in 1622.

In his Voyage d'Espagne (Paris, 1665), the French traveller A. de Brunel noted that even when based on Greck or Roman tales the plays he saw in Madrid were enacted in Spanish dress. ${ }^{10}$ This observation indicates that in the Golden Age most characters appeared on the stage in contemporary garb. However, the frequency of colour citations in both script directions and dialogue suggests that if period authenticity was irrelevant, the colour of a character's dress was not. 'The Golden $\Lambda$ ge dramatist appears to have manipulated colour for its symbolic value, to communicate a certain "extra knowledge" regarding a character's personality.

unoriginal - as in Tirso's Tanto es lo de más como lo de menos the Prodigal is called I iberio and his destimation is Egypt-it has been omitted from this study.

6 In Spanish drama, a comcdy, or comedia, is any script drama, tragedy, or comedy - which unlike the auto sacramental and morality play is not written specifically for the religious stage. For greater clarity, that definition is adhered to throughout this paper.

7 José Sancho Rayon, ed., Colección de libros españoles raros o curiosos: C'omedias inéditas de Frey Lope de Vega Carpio (Madrid: Imprenta de M. Rivadeneyra, 1873). The autograph manuscript (Madrid, Biblioteca Nacional, cat. no. 2762) is dated in 'Toledo, 12 Scptember 1604.

8 For the dating of this play and for Tirso's possible wrangle with the censors (the 1627 version may be the corrected draft of an earlier banned one), see Alan K. C. Patterson, "Tirso de Molina: Two Bibliographical Studics," Hispanic Review, xxxv (1967), 43-68.

9 The script is one of a group of ninety-six anonymous midsixtcenth-century plays preserved in a codex in Madrid's Biblioteca Nacional (Ms. 14711).

10 Antoine de Brunel, Voyage d'Espagne (Paris: Charles de Sercy, 1665), 28. 
Thus in Lope's El hijo pródigo, costume directions require the Prodigal, at his departure, to dress in "a green travelling suit trimmed in silver." "When we notice that for the same scene (Fig. 68) Murillo's Prodigal wears a green suit (trimmed in gold), the significance of the colour is worth investigating.

Iope's play makes no subsequent reference to green, but as a metaphor for the Prodigal's youthful naiveté it occurs both in Tanto es lo de más como lo de menos, where the Prodigal's father refers to his son's "green age," ${ }^{2}$ and in Valdivielso's El hijo pródigo, where the Prodigal summons his servant (the personification of his own youth) by calling him "green Youth." ${ }^{13}$ In the latter play, moreover, the colour is invoked again in a later scene when the courtesan describes the Prodigal, newly arrived at the house of pleasure, as a pisaverde. ${ }^{14}$ Formed by combining the verb pisar, to step on, with the adjective verde, green, this noun is defined in S. de Covarrubias's dictionary of the Spanish language (Tesoro de la lengua Castellana o Española [Madrid, 1611]) as an empty-headed, finicky galán (dandy), one so prissy he appears to walk on his tiptoes, as if crossing a manicured garden.

I hus, for Tirso and Valdivielso, green expresses the Prodigal's shortcomings: his youthful naiveté and overweening vanity, which they, like Lope, treat as the source of the character's downfall. To propose that Murillo had a similar end in mind in choosing the shade for The Departure of the Prodigal Son does not seem farfetched. But if that inference is valid, then what is to be made of the voluminous cape thrown over the Prodigal's shoulder, its red colour so bright that it almost eclipses the green of the suit?

Although red is not cited in costume directions for any of the plays, it appears in conjunction with grcen in the dialogue of Tanto es lo de más como lo de menos. When the reckless Prodigal has squandered nearly all his inheritance, he informs his servant that he wishes to leave the courtesan's establishment dressed in green and red (encarnado), the latter a colour that conforms to his mood..$^{15} \mathrm{Al}$ though Tirso is not specific, red usually connoted joy for the Golden Age author. Hence one might infer along with S. Griswold Morley that his

11 Félix Lope de Vega Carpio, El hijo pródigo, in Biblioteca de autores españoles (Madrid: Ediciones $\Lambda$ tlas, 1963), (LVII, $59-80,68$.

12 lirso de Molina, Tanto es lo de más como lo de menos, in Biblioteca de autores españoles (Madrid: Fdiciones Atlas, 1970), ccxxxvil, 343-98, 353.

13 José de Valdivielso, El hijo pródigo, in Teatro Teológico E.spañol (Madrid: Fditorial Catolica, 1946), 1, 182-211, 183.

14 Valdivielso, El hijo pródigo, 185.

15 Tirso, Tanto es lo de más como lo de menos, 365. humour "is a very merry one, as becomes the Prodigal in his most spendthrift mood." 16

Further, the purple garment worn by the father in Murillo's series duplicates the costume directions for Lope's El hijo pródigo where Cristalio is to wear a robe of purple silk embellished with gold thread. ${ }^{17}$ For the Golden Age author this colour connoted deep, sincere, and usually requited love. Thus purple conforms to (Cristalio's symbolic role as the all-merciful, heavenly Father.

The Prodigal's brother stands behind the father in the first canvas, and in the second he witnesses the Prodigal's departure. Thus it seems clear that his role within the narrative was intended to be a positive one. His faithful, obedient position in The Prodigal Son Receives his Portion (Fig. 67), with his hands resting on the finials of the father's chair, and his tear-stained face in The Departure of the Prodigal Son (Fig. 68) suggest his heartfelt grief. The purpose of that characterization, however, is not obvious, particularly since the traits highlighted in the Bible are his censurable selfrighteousness and envy.

A characterization as generous as Murillo's occurs in Tirso's Tanto es lo de más como lo de menos. The elder brother Modesto, a name befitting his humble, moderate nature, is developed as the prudent antithesis of the Prodigal Liberio. Tirso adroitly turns Modesto's angry outburst following the Prodigal's return, a scene vital to the denouement of the parable, in his favour. The brother rejoices in the finale:

[Liberio] softens my heart.

Say no more, a thousand times over

my brother, I welcome you.

(To the father) He is your son. I want to fête him with the others,

as it is worth more to convert

a son than to engender him. ${ }^{18}$

Not without reason are Modesto's virtues highlighted. In accordance with the title of the play (loosely translated, "too much is as bad as too little"), he provides the audience a correct alternative to the foolish excesses of the Prodigal. Indeed, Modesto is the script's only correct role model,

16 S. Griswold Morley, "Color Symbolism in Tirso de Molina," Romanic Review, vir (1917), 77-81, 80. Since encarnado also refers to flesh colour, Lope uses the word for its literal as well as symbolic value. Stripped of his belongings, the Prodigal will leave the courtesan naked, yet his mood as ho approaches that climax is one of giddy merriment. ()n colour symbolism in (;olden $A$ ge literature, sec Herbert $A$ Kenyon's fundamental article, "Color Symbolism in Farly Spanish Ballads," Romanic Rerieu, vi (1915), 327-40, and William L. Fichter, "Color Symbolism in Lope de Vega," Romanic Review, xvı1 (1927), 220-31.

17 I.ope, El hijo pródigo, 64.

18 Tirso, Tanto es lo de más como lo de menos, 365. 
offsetting the inverse excesses of the two other principal characters, the starving beggar Lázaro and the rich glutton Nineucio. ${ }^{19}$

For the painter, the two brothers are as physically alike as twins. In The Prodigal Son Receives his Portion, they are dressed almost identically and turned towards one another at a 45-degree angle so that the effect is almost that of mirror images. For Murillo the siblings define a polar choice, the elder personifying virtue, the younger, marked even from the start by his diagonally-tied black sash, its opposite.

More difficult to account for is the old woman emerging from the shadows at the left of The Prodigal Son Thrown Out (Fig. 70). Although one of the scripts cited in this study, Miranda's Comedia pródiga, includes such a figure (Briana), she is not present at the Prodigal's expulsion; and although a similar hag (the procuress) occurs frequently in sixteenth- and seventeenth-century northern European representations of the parable, she invariably appears in the preceding scene, at the Prodigal's feast.

But when creating his character, Murillo need not have recalled either of these sources. In the Golden Age theatre there existed a stock character named Celestina, an aged, tricky go-between conceived in 1499 by the playwright Fernando de Rojas. ${ }^{20}$ Her popularity was such that in La prueba de los amigos Lope could clarify the courtesan's plot simply by invoking her name. When attempting to persuade the Prodigal's servant Galindo not to interfere in the trickery she and her mistress are plotting, the handmaiden Clara asks him whether he has read Rojas's Celestina. Galindo replies affirmatively. ${ }^{21}$

However, it is still unclear why Murillo produced such a crone for The Prodigal Son Thrown Out, brandishing a stick in her right hand while admonishing the fleeing Prodigal with her left. The scene as it appears in Lope's El hijo pródigo offers a solution. In the play, the Prodigal's rude

19 Throughout the play Liberio and Nineucio represent the extreme of too much, the starving Lázaro too little, and the prudent Modesto the correct middle path. As Jaime Asensio ("Sobre Tanto es lo de más como lo de menos de Tirso de Molina," Reflexion, II [1973], 35) has observed, the inconsistency presented by the final verses where the father advises Liberio that virtue is to be found in walking Lázaro's middle path probably resulted from amendments imposed upon Tirso by the censor, the Church objecting to his criticism of the virtuous beggar.

20 Rojas wrote part if not all of the play (Comedia de Calisto ) Melibea) whose earliest known edition is the Burgos version of 1499. See Angel Valbuena Prat, Historia de la literatura española (Barcelona: G. Gili, 1968), I, 387-89.

21 Lope de Vega, La prueba de los amigos, in Obras de Lope de Vega (Madrid: tip. de la Rev. de arch., biblio. y museos, 1929), XI, 99-136, 107 dismissal from the favours of the courtesan Deleite (Pleasure) and her handmaiden Engaño (Deceit) is used to express that sinner's spiritual awakening (desengaño) to the vanity, or emptiness, of life's momentary pleasures. Spain's seventeenthcentury moralists regarded this process as essential to salvation (desengaño preceded repentance), and it is lengthily developed in Lope's script through dialogue. The Prodigal berates the courtesan:

Oh house of confusion!

When I brought my youth

and my money here

your joy received me,

your will opened before me.

I consumed my youth,

and spent my money

in your delight, which was

a crocodile for me; ...

From you I get sickncss

dishonour, infamy, poverty...

Oh vile Pleasure, and how poor

are your feigned delights!

You receive with (musical) instruments

but bid your farewells with blows . . ${ }^{22}$

When Engaño counters this outburst, reminding the Prodigal that she did not trick him since he knew her name from the start, the remorseful Prodigal replies:

\author{
Youth has no \\ greater error, \\ than to see its deceit, \\ and follow it. ${ }^{23}$
}

Since Murillo makes this episode (one not even included in the Gospel text) the subject of an entire painting, it seems fair to propose that he too intended it to express the Prodigal's desengaño, and this theory is confirmed by the figure of the old crone. As the fleeing Prodigal turns back to catch one last glimpse of his pursuers, his eyes focus on that woman, whose message could not be clearer. Positioned as she is behind the young courtesans, she recalls to the Prodigal the vanity of all earthly pleasures: the beautiful courtesans, desirable today, will soon be as she is now, vile and hideous.

Lope's El hijo pródigo also explains a curious compositional detail of Murillo's third painting, The Prodigal Son Feasting (Fig. 69). In contrast to Callot's print (Fig. 73), the Prodigal is the only one drinking, and he is depicted precisely as he accepts the proffered goblet, his fingers closing around the stem. Thus the drink seems to assume some importance. Indeed, in the script it is crucial.

22 Lope, Ell hijo pródigo, 75-76.

23 Lope, El hijo pródigo, 75-76. 
Called the wine of olvido, or forgetfulness, it robs the Prodigal of his memory and promotes his downfall. While characters personifying vices encourage him to drink, musicians sing:

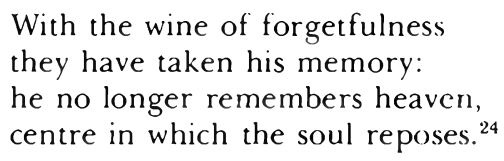

In Valdivielso's El hijo pródigo, the potion becomes synonymous with the carnal pleasures of the harlot. Carrying these within her chalice, Lascivia appears on the stage arrayed as the Babylonian Whore, that biblical nemesis described in Revelations 17:4. The dandy Placer introduces her to

the tune of sweet lutes,

zythers, harps, guitars,

bewitching voices cry

of beautiful sirens...

[she] covered in gold and pearls,

because she turns men into bcasts,

she enters upon a beast,

a chalice in her hand.

within which she carries her pleasures. ${ }^{25}$

The concept of man figuratively transformed into a beast through the wiles of a female corruptor is also present in Lope's scripts. In La prueba de los amigos, Galindo remarks that the courtesan Dorotea, a character earlier compared to Circe and Medea, converts men into beasts, ${ }^{26}$ while in $E l$ hijo pródigo, after consuming the wine of forgetfulness, the Prodigal is compared to the legendary Ulysees and reminded that his indulgence will earn him the same fate. ${ }^{27}$ Indeed, the concept is central to a score of seventeenth-century plays, including the mythological auto Los encantos de la culpa, written by Calderón de la Barca about 1649. In the play, the character of Man falls aslcep, relaxing the guard over his five senses. Lnattended, they are bewitched by the beautiful La (Culpa, who transforms them into beasts: sight becoming a tiger, touch a bear, taste a mute brute, smell a lion, and hearing a chameleon, a condition from which only Man, armed with his understanding, will be able to rescue them. ${ }^{28}$

In Murillo's composition the Prodigal's senses are not clearly defined, but allusions to each are offered. For example, by gazing at the courtesan and embracing her, he engages his touch and sight; the feast before him, in turn, will indulge his senses of taste and smell, while the lute player

24 Lope, El hijo pródigo, 71.

25 Valdivielso, El hijo pródigo, 188

26 Lope, La prueba, 108.

27 Lope, El hijo pródigo, 71

28 Pedro Calderón de la Barca, Los encantos de la culpa, in Obras Completas (Madrid: Aguilar, 1967). 406-21. seated in the left foreground offers music to delight his hearing.

The definition of the senses is no less subtle in Lope's El hijo pródigo, but in verses their presence is made fact. Stage directions for the banquet require a servant to enter bearing a light supper, a musician to strum a lute, and the Prodigal, holding hands with the courtesan Deleite, to drink the wine of forgetfulness. Meanwhile, a chorus intones:
Blind is his understanding, his will is impassioned, over his five senses Pleasure has been victorious.
Pleasure, highwayman of fortune and honour, her eyes are on his... ${ }^{29}$

Murillo's painting neatly parallels Lope's words. While the Prodigal takes his drink with his right hand, his left encloses the courtesan and draws her to his side. She looks amorously into his eyes. Although he seems to return her gaze, closer inspection reveals that his pupils, painted an opaque grey, stare dully out into space, as if in blindness.

Quite opposite is the penetrating look which the Prodigal exchanges with his father in the sixth and final painting, The Return of the Prodigal Son (Fig. 72 ). With their heads so close they seem to touch, each staring deeply into the other's eyes, the arrangement of characters differs significantly from the seventh print of Callot. There the father and son, so tiny their features are barely distinguishable, survey one another at arm's length.

Valdivielso's El hijo pródigo explains Murillo's composition. Awaiting his son's imminent return, the father urges him to be "blind no more," while upon his arrival he instructs him to "look into these eyes, they are clemency." ${ }^{30}$ Accordingly, the father's tender gaze reflects his mercifulness and the large eyes of the Prodigal the return of his clear vision and the renewed purity of his soul.

Although Valdivielso's interpretation accords with Murillo's, a scant three lines of dialogue cannot support an argument that the script served the painter as a source. Rather, it indicates that two artists shared a common understanding of one event. The Prodigal's feast is a different case altogether. Stage directions and dialogue for Lope's El hijo pródigo define a scene so similar to Murillo's that the source seems overwhelmingly established.

Sadly, one cannot prove that Murillo ever saw the play. The archives of Seville rarely record the titles of plays staged in that city during the seventeenth century. And though we know that religious scripts were produced-for the feast of

29 Lope, El hijo pródigo, 71

30 Valdivielso, El hijo pródigo, 209. 
Corpus Christi as many as four annually ${ }^{31}$ - one cannot assume that El hijo pródigo was staged during Murillo's lifetime. Lope had been dead since 1635 and, although he was not forgotten, the sophisticated autos of Philip Iv's favourite playwright, Calderón de la Barca, were in fashion.

Calderón, however, never based a play upon the parable (perhaps he judged it overinterpreted). So, discounting Valdivielso's derivative script, Lope's was still the most modern adaptation available. Included - somewhat illogically - in the author's romantic adventure novel El peregrino en su patria (Seville, 1604), the play's availability to Murillo cannot be doubted: within fifteen years of its publication this popular book had been reissued six times. ${ }^{32}$

Although he could have read El hijo pródigo, and may even have seen it enacted, the question remains why Murillo required a script source at all. Perhaps Callot's version of the Prodigal's feast seemed overly exuberant for Spanish tastes. It was also unspecific regarding the nature of the Prodigal's sin. But why did the artist not use a native pictorial source?

The answer to the question is startling: apparently there was none. A scene that could be categorized among northern Europe's most popular pictorial themes was roundly ignored in the peninsula. Not only does Murillo appear to have been the first Spanish artist to illustrate the Prodigal's dissipation, but he was also the first to represent the taking of his portion, his departure, and his dismissal by the courtesans. Only the two episodes that offered good illustrations to the popu-

31 José Sánchez Arjona, El teatro en Sevilla en los siglos XVI y XVII (Madrid: Estab. tip. de A. Alonso, 1887), 58.

32 The known seventecnth-century editions of El peregrino are: Seville, 1604; Barcelona, 1604 (2); Madrid, 1605; Barcelona, 1605; Brussels, 1608; and Madrid, 1618. After 1618 the book was not reissued until the late eighteenth century. lar Counter-Reformation theme of penance, the repentance and the return, generated any earlier interest whatsoever. ${ }^{33}$

Scenes of sin were never popular with Spanish artists, and those of carnal sin particularly were anathema. Thus the omission is decidedly relevant and explains why so many parallels exist between Murillo's narrative and the Spanish stage. Interpreting scenes that had been attempted by no other Iberian painter, Murillo looked to the prints of a neighbouring Catholic artist for inspiration. In the creative process he radically transformed that source, introducing colour, replacing action with psychological drama, supplying new characters, costumes, and settings - in short, converting Callot's early seventeenth-century French world into that of late seventeenth-century Spain. Indispensable to that process was the Golden Age stage. Although we cannot know precisely to what extent the Spanish theatre served him, clearly it is the only source from which inspiration could have come. The close similarity which Murillo's third composition bears to the scene as dramatized by Lope proves the painter did turn there. To be sure, he could have touched no richer vein. In the scripts of Lope, Tirso, and Valdivielso, three of Spain's finest seventeenth-century playwrights, Murillo could have gleaned all the inspiration he required.

33 On the theme of penance in Counter-Reformation art, see Emile Mâle, L'art religieux après le Concile de Trente (Paris: A. Colin, 1932). Murillo too developed each of the scenes individually: The Repentance of the Prodigal Son, a canvas of unknown provenance auctioned at Sotheby's (London) in 1973; and The Return of the Prodigal Son (Washington, D.C., National Gallery of Art), one of six canvases representing examples of the Acts of Charity drawn from the Bible (the return illustrating the clothing of the naked) completed by Murillo in 1670 for Seville's Church of the Brotherhood of Charity. Both paintings are catalogued by Angulo Iñiguez, Murillo, II, cat. nos. 83 and 238 . 


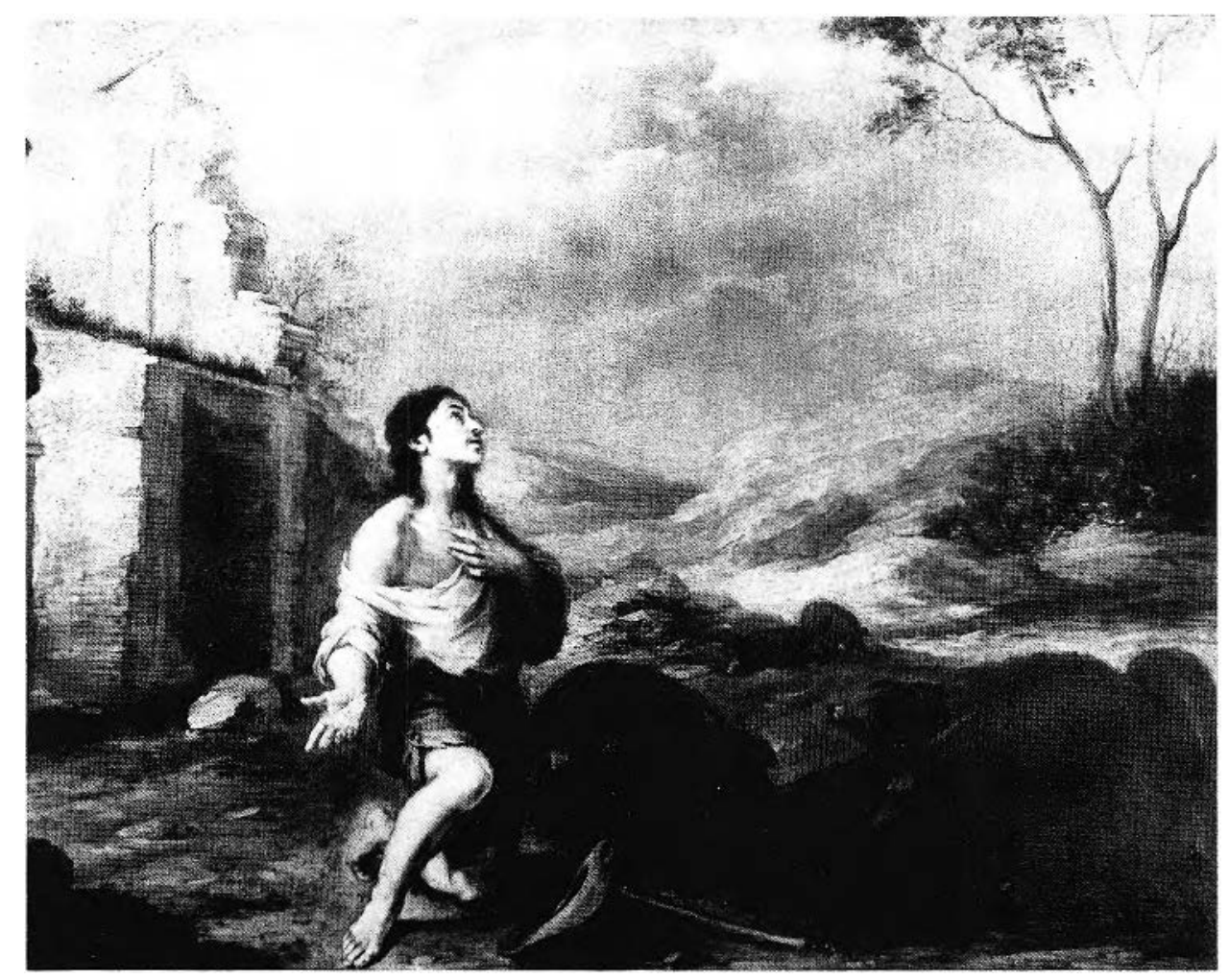

Figtre 71. B. E. Murillo, The Repentance of the Prodigal Son $(105 \times 135 \mathrm{~cm}$.$) , ca. 1660-70$. Blessington, Beit Foundation (Photo: Beit Foundation).

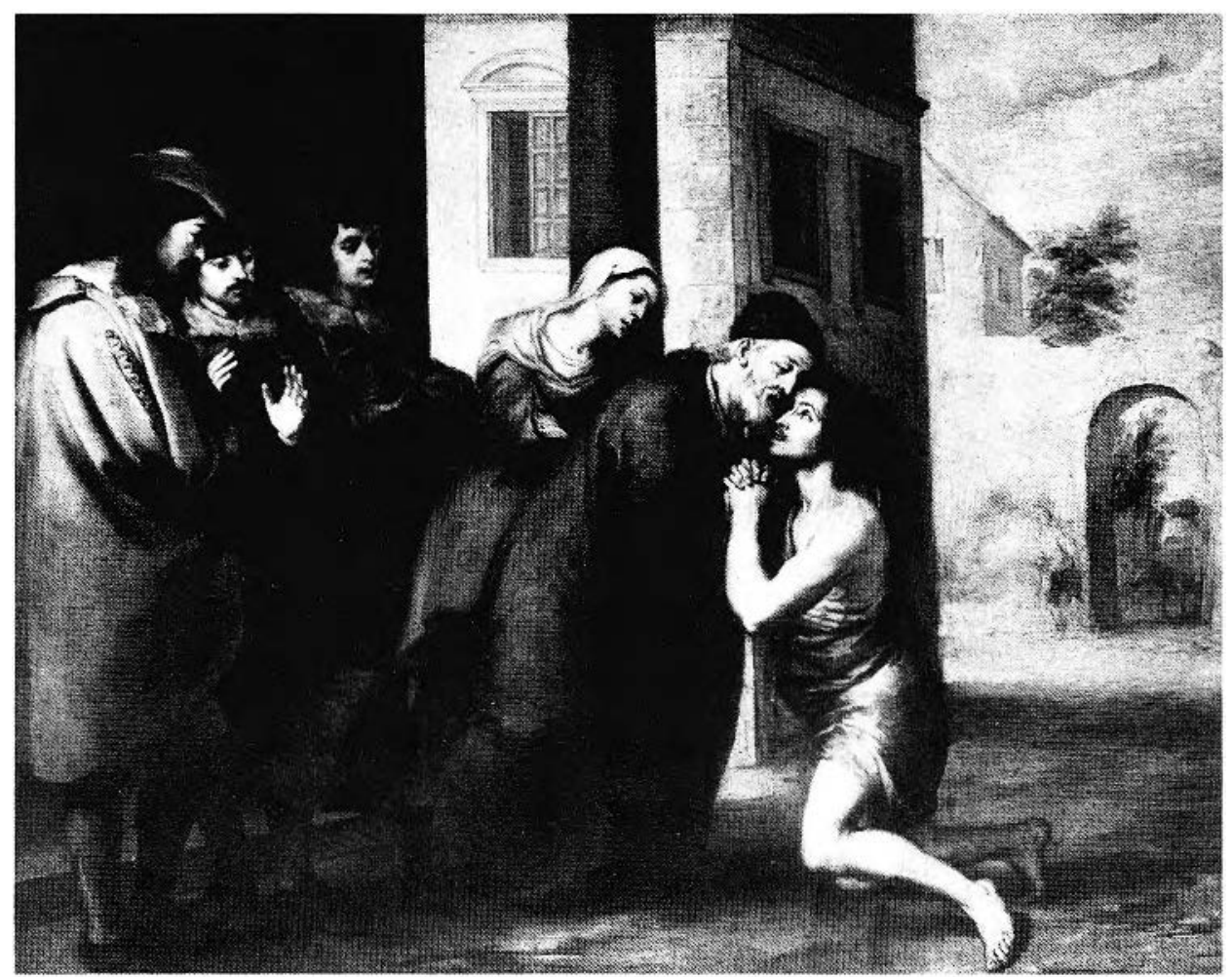

Figure 72. B. E. Murillo, The Return of the Prodigal Son $(105 \times 135 \mathrm{~cm}$.), ca. 1660-70. Blessington, Beit Foundation (Photo: Beit Foundation). 


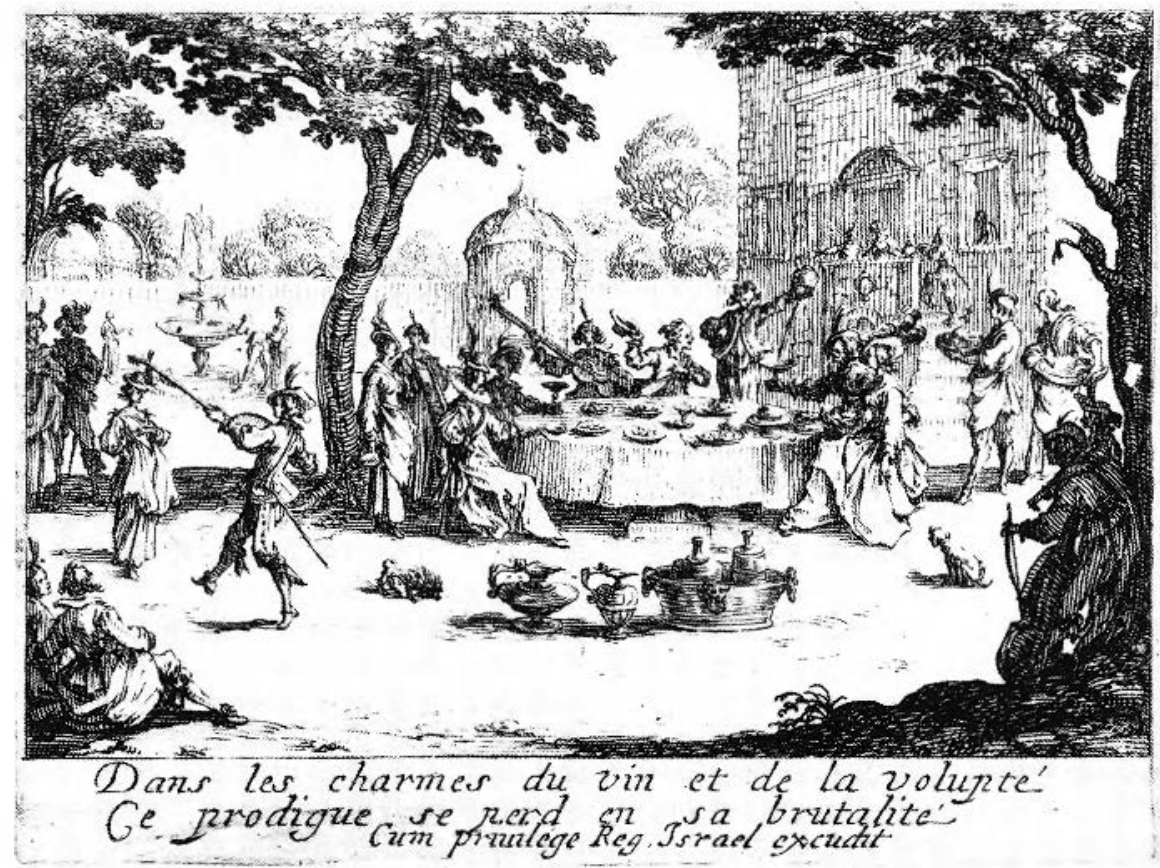

lis irke 73. J. Callot, The Prodigal Son Feasting $(525 \times 790 \mathrm{~mm}$.) (Photo: The Art Museum, Princeton Lniversity, Princeton, N.J.).

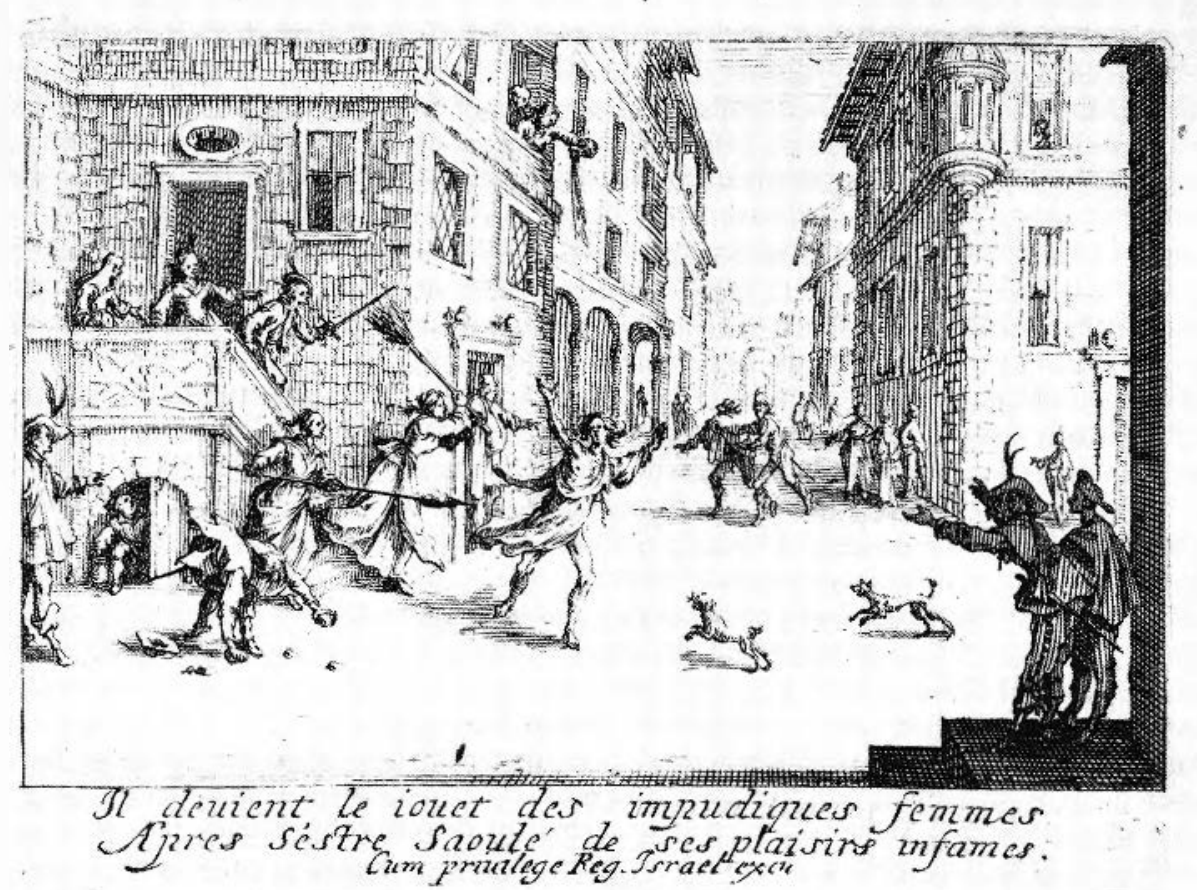

Finere 74. J. Callot, The Prodigal Son Throun Out $(530 \times 805 \mathrm{~mm}$.) (Photo: The Art Museum, Princeton University, Princeton, N.J.). 